\title{
DO TAXES INCREASE ECONOMIC INEQUALITY? A COMPARATIVE STUDY BASED ON THE STATE PERSONAL INCOME TAX
}

\author{
Ugo Troiano \\ Working Paper 24175 \\ http://www.nber.org/papers/w24175 \\ NATIONAL BUREAU OF ECONOMIC RESEARCH \\ 1050 Massachusetts Avenue \\ Cambridge, MA 02138 \\ December 2017
}

I thank Lorenzo Casaburi and Mark Dincecco for helpful conversations. All mistakes remain mine. The views expressed herein are those of the author and do not necessarily reflect the views of the National Bureau of Economic Research.

NBER working papers are circulated for discussion and comment purposes. They have not been peer-reviewed or been subject to the review by the NBER Board of Directors that accompanies official NBER publications.

(C) 2017 by Ugo Troiano. All rights reserved. Short sections of text, not to exceed two paragraphs, may be quoted without explicit permission provided that full credit, including $\odot$ notice, is given to the source. 
Do Taxes Increase Economic Inequality? A Comparative Study Based on the State Personal Income Tax

Ugo Troiano

NBER Working Paper No. 24175

December 2017

JEL No. D63,H23,N32

\begin{abstract}
I present new quasi-experimental evidence on the relationship between tax policies and the distribution of income. I focus on the twentieth century United States, and on the personal income tax, since its inception. I study three major policy events that, as the existing literature shows, significantly raised the revenues from the income tax: the introduction of the state personal income tax, the introduction of tax withholding together with third-party reporting, and the intergovernmental agreements between the federal and state governments to coordinate tax auditing efforts. All the three policies were introduced in a staggered fashion and increased tax revenues, but had different fiscal consequences. Despite this, I find that income inequality raised after all the tax policy events. The result is robust to different measures of economic inequality and econometric specifications.
\end{abstract}

Ugo Troiano

Department of Economics

University of Michigan

611 Tappan Street, Lorch Hall 219

Ann Arbor, MI 48109

and NBER

troiano@umich.edu 


\section{Introduction}

The conventional wisdom is that taxes can help in reducing inequality and in redistributing income (Burman , 2015). ${ }^{1}$ However, tax reforms are typically not randomly assigned in time and space, and little is known on whether and how taxes reduce inequality. This paper aims at filling this gap, and providing new quasi-experimental evidence about the relationship between taxes and inequality. My findings go against the conventional wisdom. I analyze three case studies in the twentieth-century United States, and in all three of them I find that taxes significantly increase economic inequality.

One of the main rationales for having taxes is to correct market failures, which include having an unequal distribution of income. Burman (2015) argues that the creation of the individual and corporate income taxes was largely motivated politically by "concerns about equity." Despite this, little is known about whether tax policies have a causal effect in reducing economic inequality.

The question is a hard one for at least three reasons. First, economic migration (Feldstein and Vaillant , 1994). People may just move out of the jurisdiction that is increasing taxes toward places with less taxation - and this is indeed what happened when US states introduced the income tax. Second, places that decide to increase taxes may be different than places with less taxes. For instance, their voters may care more about economic inequality, or may be more prone to fiscal discipline. Third, the timing of the tax policies reforms may not be as good as randomly assigned because the jurisdictions may decide to increase taxes when there are revenue needs. Additionally, reforming tax systems in order to reduce inequality may be related to political considerations and not be as good as randomly assigned (Leigh , 2005).

In this paper I consider three case studies taken from the United States history. All the case studies have in common to be about the state personal income tax. The personal income tax has steadily increased its importance as revenue source for states, see Figure 1, despite the fact that taxes are loosing their importance as revenue sources as opposed to transfers and other revenues, see Figure 2.

The three major reforms that I will analyze are: (1) the state income tax introduction, (2) the introduction of withholding, bundled with the introduction of third-party reporting, and (3) the intergovernmental agreement between the federal and the state governments for coor-

\footnotetext{
${ }^{1}$ Feldstein and Vaillant (1994) argue that state taxes can not redistribute income if people migrate out of the jurisdiction as a response to the additional fiscal pressure.
} 
dinating auditing practices. The fiscal consequences of these reforms have been analyzed by three recent studies: Cassidy, Dincecco and Troiano (2017), Dusek and Bagchi (2017), Troiano (2017), respectively. All of the studies find that the state revenues from personal income tax increased as a result of the policies.

However, for what matters the rest of the outcomes, the studies have different findings. For instance, while there has been economic migration following the introduction of the income tax, there not have been population responses following the other two policy events. The introduction of the income tax was also accompanied by changes in other part of the budget, such as expenditures in education, and even increase in educational outcomes, such as the number of public colleges in a given state (Cassidy, Dincecco and Troiano, 2017).

In this study I focus on the distributional aspect of these tax reforms. To the best of my knowledge, this is the first paper analyzing quasi-experimentally the distributional aspect of the tax reforms of the United States, and it complements existing papers about the relationship between inequality and taxation with analysis of data that do not suffer the limitation of few cross-sectional or time units, as it often happened in the past with studies about income inequality (Piketty and Saez, 2003).

In order to alleviate the aforementioned statistical concerns, I follow the methodology of the three previously cited studies in adopting a difference-in-differences identification strategy. The slight differences between this and the previously mentioned three studies is in the sample (mine is a balanced panel that goes from 1917 to 2015, while theirs is either unbalanced or covers a shorter time span), and in the robustness tests. The main idea of the identification strategy is to compare economic inequality in the states that underwent the tax policy reforms and those that did not, before and after the policy change of interest.

The methodology has two main assumptions. The first one is that the treatment and control group have to be on parallel trends before the policy change. Absent this, one would not be able to ascribe the change in the series to the policy of interest, because of the confounding pre-existing difference. The second assumption is that there should not be other contemporaneous policy events affecting differentially the treatment and control group.

While checking whether the first assumption is verified is relatively straightforward, verifying the second assumption is trickier because it requires either institutional work to rule out contemporaneous policies, or augmenting the standard framework with additional assumptions. In this study I will verify both assumptions, sometimes with institutional work (this will be the case for the introduction of the income tax) or with additional assumptions 
(for the introduction of withholding and the audit information exchange agreement).

My main finding is the following: the major tax reforms of the twentieth US increased the states' economic inequality, regardless of the inequality measure used and of the specification. For instance, in a difference-in-differences specification that controls also for state specific linear trend, introducing the income tax raised the Atkinson index by 1.5 percentage points, 7 percent of its sample mean; introducing third party reporting and tax withholding raised the Atkinson index by 1.1 percentage points, about 6 percent of its sample mean; the audit information exchange agreement between the federal and the state governments raised the Atkinson index by 0.9 percentage points, which is about 4 percent of its sample mean. ${ }^{2}$

An important caveat that should be noted and that will be discussed in more detail later is that the inequality measures used in this paper derive from the IRS administrative data. While this has obvious advantages of data reliability, it comes with the cost that the data derive just from the filers of the income tax, which were relatively few before 1944. Therefore, the results of the introduction of the income tax, which is the only policy reform for which data before 1944 are relevant, should be interpreted keeping this important caveat in mind. It is however re-assuring that the results for the introduction of the income tax are qualitatively similar to those of the other two reforms.

This paper fits in the literature about the economic consequences of tax reforms for income. The literature about behavioral responses to taxation is reviewed by Saez, Slemrod and Giertz (2012). In a world without externalities, identifying the elasticity of taxable income with respect to tax reforms is sufficent to conduct welfare analaysis. Empirically, there is strong evidence that people respond to taxation, for instance Saez (2016) finds that the 2013 tax increase of the top marginal rate had a large negative effect on reported income at the top. People respond to taxation not only in terms of reported income but also labor supply, mobility, fertility and other important margins. Additionally, it is possible that not only the people that are statutorily targeted by a tax reform are the ones responding via the reported income. This paper contributes to this literature by showing that, if the tax policy reforms of the twentieth century US were introduced to correct the inequality externality, they failed their intent, because inequality raised, instead of lowering.

The paper contributes also to the scientific literature focused specifically on economic inequality, which in the last years has been extremely active. The authors in this literature are

\footnotetext{
${ }^{2}$ I always control for state specific linear trends because the inequality measures are relatively predictable out-
} comes. Not controlling for state specific linear trends make my results even stronger. 
undertaking two directions. The first one is studying income inequality (Golding and Margo , 1992, Feenberg and Poterba , 1993, 2000, Frank , 2009, Atkinson, Piketty and Saez , 2011). The second one is studing wealth inequality (Saez and Zucman, 2016, Johannesen and Zucman, 2014, Alstadsaeter, Johannesen and Zucman , 2017).

The paper proceeds as follows. In Section 2 the institutional framework and data are presented. In Section 3 I describe the empirical strategy. In Section 4 the results are presented. In Section 5 I present the robustness tests. In Section 6 I conclude.

\section{Institutional Framework and Data}

In this section I describe the institutional framework and the data used in the analysis. There are two sets of data. The first one is composed of the inequality measures used in the analysis, and the second one is about the tax policies I am focusing on. The variables are summarized in Table 1.

\subsection{State Tax Policies}

The setting of this study is the twentieth century United States. Throughout that century, three big events have happened related to the personal income tax (Penniman , 1980): its inception, the introduction of tax withholding (bundled with third-party reporting), and the intergovernmental audit exchange agreements between the federal and state governments. This sub-section borrows heavily from (Penniman , 1980). The timing of the policy reforms is summarized in Table 2.

The first modern income state tax was enacted by Wisconsin in 1911, "at the height of his political progressivism" (Penniman , 1980). Before 1920, Delaware, Massachussetts, Mississippi, Missouri, New York and North Dakota followed. Despite these early adopters, there is a substantial body of evidence, summarized by Penniman (1980), that there was a lot of political opposition to state income taxes. She writes:

Yet, in a majority of the states, it took decades to win acceptance of the income tax as a policy choice and to develop individual and corporate income taxes somewhat near their potential for raising revenue.

The institutional work undertaken by Clara Penniman clearly shows that the specific year 
of adoption of the state income tax was not only due exclusively to considerations about revenue needs, that instead could have been fulfilled through other means, such as fees and tariffs, but was also due to state-specific political considerations. Therefore, it is unlikely that there is a policy systematically correlated with the adoption of the income tax at the state level and that could bias the results. To further corroborate this point, Cassidy, Dincecco and Troiano (2017) consider for a number of states (the ones for which data could be collected) how close the legislature vote that introduced the state income tax was, and show that the revenue increase following the income tax is not too different in states where the vote was close from those where the vote was not close.

Tax withholding was introduced together with third-party reporting in the United States (Dusek and Bagchi, 2017). The possibility of collecting taxes directly at the source seemed very appealing for policymakers, so as to avoid the work of identifying many non-filers, and, among the reasons officially cited for this reform, there was equity in tax administration (Penniman , 1980). Oregon was the first state to adopt withholding for wages and salaries (but not for other income) in 1948. By the early 1970s, almost all the income tax states had adopted withholding. Therefore withholding is not only an innovation on how to collect income, but it was partly also a tax enforcement technique, and a mean of "automatic tax budgeting" for the taxpayer. Penniman (1980) writes that "the timing of adoption in each state varied with fiscal need, with the extent of personal exemptions and with state tax rates." While fiscal need and state tax rates are endogenous to the policy, one could use the exogenous component of personal exemptions to alleviate the identification concerns. That is the strategy I will adopt in one of the robustness tests later on.

The third policy is the information exchange audit agreements. Those are voluntarily signed agreements between each state and the federal government, and that involve exchange of information on audit plans and techniques. ${ }^{3}$. The first test of this policy was authorized in 1950 for the states of North Carolina and Wisconsin. What happened during the first period of the policy is that one group of agents for each governmental unit (one for the government, one for the state) prepared reports about the audited returns showing a deficiency in tax, and mutually exchanged these pieces of information about those returns. Later on, during the 1970s, cooperative auditing developed, also thanks to technological innovation, and the program arrived to the point that in some states the federal government and the states divided

${ }^{3}$ On tax enforcement and the relationship between different layers of government see also Casaburi and Troiano (2016) 
the ex-ante the work, with the state having the task of auditing the smaller returns, while the federal government covering the bigger returns.

\subsection{Inequality Measures}

The baseline inequality measures that I use are the Atkinson index, the Gini coefficient, the Relative Mean Deviation and the Theil index. The data come from Frank et al. (2015). The advantage of those measures, is assessing the inequality over the entire income distribution, as opposed to focus only on what happens at the top or at the very top of the income distribution. In the Robustness test section, I will report the results for the rest of inequality measures (share of income at the top 10, 5, 1, 0.5, 0.1 and 0.01 percent).

All of these inequality measures are constructed from administrative data provided by the IRS to researchers, the Statistics of Income, by state-year and by size of the adjusted gross income in the individual tax returns. The pre-tax adjusted gross income in individual tax returns include wage and salaries, capital income and entrepreneurial income, and it does not include interest on state and local bonds, and transfer income from federal and state governments.

The main drawback of using inequality measures that include the full distribution of income with IRS data is that the data are truncated at the low-end of the income distribution because of the non filers. Therefore, it is reassuring that the results are robust when looking at the shares, in the Robustness tests section. The problem of the non-filers is more pervasive before the 1944 (Piketty and Saez , 2003, Frank , 2014).

The Atkinson index is a social welfare function based measured of inequality and it is bounded between 0 and 1 , with an inequality aversion parameter of 0.5 , meaning that the function is more sensitive to what happens in the upper end of the income distribution. The Gini index varies between 0 and 1 and tends to be sensitive to what happens in the middle of the income distribution. The Relative Mean Deviation is bounded between 0 and 2, and represents the normalized average distance between each person's income and the mean income of the population. The Theil index is an unbounded measure of income inequality derived from statistical information theory and is defined as the maximum possible entropy of the data minus the observed entropy. All of the four measures are increasing in economic inequality.

Frank (2014) observes how over the last century the Theil index appears to closely follow 
the trend of the 1 percent of the income distribution, while the other three measures have an important difference with the shares of the income distribution: the decrease in inequality after the Great Depression and the Second World War is "not as precipitous."

\section{Empirical Strategy}

In this section, the empirical strategy is outlined. Following Cassidy, Dincecco and Troiano (2017), Dusek and Bagchi (2017), Troiano (2017), I implement a difference-in-differences approach based on the staggered introduction of the tax reforms. My aforementioned contribution is analyzing quasi-experimentally the effect of tax policies on the distribution of income. The baseline specification is therefore:

$$
D_{i t}=\beta_{0}+\beta_{1} \text { Post }_{i s}+\phi_{i}+\phi_{t}+\phi_{i} * T_{s}+\epsilon_{i s t}
$$

The dependent variables D are the inequality measures (Atkinson index, Gini coefficient, Relative mean deviation and Theil index) in state $i$ and year $t$. The dummy Post is equal to one after one of the policy reforms of interest. The state and year fixed effects, $\phi_{i}$ and $\phi_{t}$, control respectively for place-specific and time-specific shocks, and $\phi_{i} * T_{s}$ control for state specific linear trends. The standard errors, $\epsilon_{i s t}$, are robust to heteroskedasticity and clustered at the state level. The coefficient of interest $\beta_{1}$ captures the causal effect of the tax reform on the distribution of income under plausible assumptions.

I focus on those inequality measures because, after 1944, they plausibly capture the full distribution of income, rather than just what happens at the very top. However, the results are robust to using the shares of top incomes used by Piketty and Saez (2003). The dataset goes from 1917 to 2015.

One potential challenge to the identification is that the adoption of the policy changes may be correlated with past trends in the distribution of income, or other relevant variables such as fiscal policy. If this were the case, for instance because the policy reforms are undertaken when the revenue requirements are higher, the identifying assumptions would be violated. The plausibility of this important concern can be verifiyed in this setting. If the tax reforms are exogenous to past policies, one would expect that the pre-trends in policies in the treated and control states are parallel before the change, and diverge only after the introduction of the income tax. The assumptions are verified below. 
Another challenge to the identification is the possibility that the timing of adoption of the policies may be systematically correlated with other policies. This is an important factor and the way to deal with it will vary from case to case. First, for the introduction of the income tax, Penniman (1980) verified institutionally that the reasons were largely idiosyncratic and political, and that states had other ways to raise revenues. Cassidy, Dincecco and Troiano (2017) conduct an additional robustness check. They look at how close the vote to introduce the income tax was, and they split the sample in places where the vote was close, and places

where the vote was not close. They show that the increase in tax revenues is statistically similar in those place, providing suggestive evidence that Penniman's claims are right. For the other two policy reforms, Penniman does not suggest that the timing of adoption was quasi-random or idiosyncratic. Therefore, we provide additional robustness tests, described below in the results section.

\section{Main Results}

In this section, I investigate quasi-experimentally the consequences of the tax reforms on the inequality measures. For each inequality measure, I present the baseline specification, a standard difference-in-differences with linear time trends. I present the effect of the three policy reforms in the following order: introduction of the income tax, introduction of withholding and audit information exchange agreement.

In Table 3 one can see that the introduction of the income tax raised the Atkinson inequality index by 0.015 , which is about 7 percent of the sample mean, statistically significant at the 1 percent level. Introducing the withhholding raised the Atkinson index by about 6 percent, statistically significant at the 5 percent level, and the audit exchange agreement raised it by about 4 percent, statistically significant at the 1 percent level. In Table 4 the Gini coefficient is presented. The income tax introduction raised the Gini coefficient by 0.014 , which is about 3 percent, significant at the 5 percent level. The introduction of withholding raised the Gini coefficient by about 1 percent, but this is not significant at standard levels.

In Table 5 we move to consider the Relative Mean Deviation. The introduction of the income tax raised the Relative Mean Deviation by 0.027, which is about 3 percent. The magnitude of the effects for the withholding and the audit exchange are about half that size, and border line insignificant at standard levels.

In Table 6 we consider the Theil index, which is the most similar to the top 1 percent of the 
income distribution. All of the three reforms raised the Theil index in a statistically significant way, at least at the 5 percent level. The introduction of the income tax and of the withholding raised it by about 0.06 , which is about one fourth of a standard deviation or one eight of the sample mean.

\subsection{Interpretation and Comparative Analysis}

In this subsection I argue, based on my own reading of the literature that the set of the results suggest that the mechanism at play that may explain the relationship between taxes and inequality is that bigger state governments favored the wealthy, rather than the middle class or the poor. I argue that others explanation receive less support from the data.

The first alternative explanation is economic migration (Feldstein and Vaillant, 1994). There is a growing body of empirical evidence according to which people move after economic shocks (Akgit, Baslandze and Stantcheva, 2015, Kleven, Landais and Saez , 2013, Liebig, Puhani and Sousa-Poza, 2006, Moretti and Wilson, 2013). If mobility were explaining these results, the econometrician would have found that people move not only after the introduction of the income tax, which is the only policy reform that affected mobility. All of the other policy reforms did not affect economic migration.

The second alternative explanation is that tax enforcement and third-party reporting disproportionately affect the middle class (Saez, Slemrod and Giertz , 2012). While such an explanation is closer to a fact than a hypothesis, because typically the very wealthy are selfemployed, that alone can't explain the results. The introduction of the income tax typically did not come as a bundle with third party reporting, and, yet, it affected inequality by raising it, when third-party reporting was not in place yet.

The third alternative explanation is that the economic expenditures in tertiary education, which raised because of the introduction of the income tax, typically benefit only the wealthy that are the ones going to college, especially in the past history. While again this explanation is based on true facts, it would not explain why withholding or the audit agreements also raised inequality, because those two policies did not affect expenditures on education.

The fourth alternative explanation is that those reforms have affected only reporting, by inducing a shift of reported income from personal to business (Gordon and Slemrod, 2000). I argue that this possibility can't explain the findings that people moved as a response to the introduction of the income tax, and that the same reform affected spending on education and 
access to colleges.

In other words, the fact that the only effect that these reforms had in common was raising the revenues from income tax and making the government bigger and the private sector smaller, suggest that a bigger government, at least in the recent history, had the effect of higher inequality.

An alternative explanation that I can't rule out is that the labor market responded to the tax reforms by changing its institutions and causing the increase in economic inequality (Piketty and Saez, 2003).

\section{Robustness Tests}

In this section I will cover the robustness tests for the main analysis. This section is divided into three parts. In the first part I discuss the assumption of absence of contemporaneous events affecting differentially the treatment and the control group. In the second part I present the pre-trends graphs for the main outcomes, and in the third part I show that my results are robust if I use alternative inequality measures (the shares of income of the top earners).

\subsection{Contemporaneous events}

One of the fundamental assumption of the difference-in-differences is that there are no other contemporaneous events that affect differentially the treatment and control group. While the assumption is not testable, it is surely respected only in a randomized evaluation. However, I aim at persuading the reader that the concerns in this setting are limited. First, for what matters the introduction of the income tax, as already mentioned in the Institutional Framework section, there are institutional reasons to believe that there were no other events that regularly associated themselves with that policy and that affected differentially the treatment and control group.

Second, for what matters the introduction of withholding, that happened bundled with third party reporting, Penniman (1980) claims that the timing of adoption in each state varied with fiscal needs, the extent of personal exemptions and deductions and with state tax rates. While the latter and the first can vary with the policy itself, the extent of personal exemptions and deductions have an exogenous component in them, the federal part. Therefore, I perform the following exercise: I collect a proxy of the federal exemptions, given by the ratio between 
the taxable income and the adjusted gross income, and I interact this proxy with another proxy: the degree of conformity of the state code with the IRS code (data about this closeness are from Penniman (1980)). I then show in Table 7 and Table 8 that the results are robust when this variable is included. ${ }^{4}$

Third, for what matters the audit exchange agreements, I follow Troiano (2017) and assume that the state and the federal government had equal bargaining power in signing the agreement. If this is true, one could alleviate the bias by controlling for the interaction between federal revenue needs and state fixed effects. In Table 9 and Table 10 I show that the results are robust to this exercise.

\subsection{Pretrends}

In Figures 3, Figure 4 and Figure 5, I investigate whether the main effects are robust to dynamic considerations, or the pre-trends are driving the results. From looking at the graphs, one can see how those variables don't exhibit statistically significant pre-trends, and there are reasonably significant jumps after the main treatments of interest.

\subsection{Additional Inequality Measures}

In Tables 11 to 16, I show that the results are robust when we use alternative measures of income inequality, the shares of income earned by top earners. The measures that are most significative, both statistically and economically, are those with a smaller fraction of rich people. For instance, after the introduction of the income tax and of withholding the fraction of income at the top 0.01 percent of people increases respectively of 0.277 and 0.415 out of a baseline mean of 1.91, both significant at the 1 percent level. Typically, the introduction of the income tax and withholding seems to have increased income concentration at the very top, while the audit exchange agreements operated at the top of the income distribution. In Figures 6 to 11, I show that the pre-trends are not driving the results described in the previous Tables, and pre-trends are arguably parallel before the policy changes.

\footnotetext{
${ }^{4}$ The results are robust when the timing of adoption is instrumented with this variable, and the results are available upon request.
} 


\section{Conclusion}

In this paper I presented new quasi-experimental evidence about the relationship between tax policies and income inequality in the United States throughout the twentieth century.

By exploiting the staggered introduction of three major policy reforms (the introduction of the income tax, the introduction of third-party reporting together with withholding, and the intergovernmental agreements between the states and the federal government to reduce evasion) and adopting a difference-in-difference identification strategy, I find that all the considered tax policy reforms raised economic inequality, instead of lowering it, as was intended by the policymakers.

The results of this paper raise several avenues for future research. For instance, are there tax policies that can help reduce income inequality? How context-dependent are the results about this paper? Would the results be different if the unit of observations were countries rather than states? Future research should investigate these questions. 


\section{References}

Akgit U., S. Baslandze and S. Stantcheva (2015). “Taxation and the International Mobility of Inventors." Working Paper.

Alstadsaeter, A., N. Johannesen, and G. Zucman (2017). “Tax Evasion and Inequality.” Working paper.

Atkinson, A., T. Piketty, and E. Saez (2011). “Top Incomes in the Long-Run of History, Journal of Economic Literature, 49(1), 3-71.

Burman, L. (2005). “Taxes and Inequality," Tax Law Review

Casaburi, L. and U. Troiano (2016). “Ghost-House Busters: The Electoral Response to a Large AntiTax Evasion Program." The Quarterly Journal of Economics, Volume 131, Issue 1, 273-314.

Cassidy, T., Dincecco, M. and U. Troiano (2017). "Broadening the State: Policy Responses to the Introduction of the Income tax." Working paper.

Dusek, L. and S. Bagchi (2017). “Third-party Reporting, Tax Collections, and the Size of Government: Evidence from Withholding." Working paper.

Feenberg, D., and J. Poterba (1993), “Income Inequality and the Incomes of Very High Income Taxpayers: Evidence from Tax Returns, Tax Policy and the Economy Cambridge, MA: MIT Press, pp. 145-177.

Feenberg, D., and J. Poterba (2000), “The Income and Tax Share of Very High Income Households, 19601995." American Economic Review, 264-270

Feldstein, M. and M. Vaillant (1994) “Can state taxes redistribute income?" Journal of Public Economics 68(3): 369-96

Goldin, C., and R. Margo (1992) "The Great Compression: The Wage Structure in the United States at Mid-Century, Quarterly Journal of Economics, 1-34.

Gordon, R., and J. Slemrod (2000)“Are Real Responses to Taxes Simply Income Shifting between Corporate and Personal Tax Bases, (2000) in Joel Slemrod, ed., Does Atlas Shrug? The Economic Consequences of Taxing the Rich (New York: Russell Sage Foundation; Cambridge, MA: Harvard University Press, 2000).

Frank M. W. (2009). "Inequality and Growth in the United States: Evidence from a New StateLevel Panel of Income Inequality Measure," Economic Inquiry, Volume 47, Issue 1, Pages 
55-68.

Frank, M. W. (2014). “A New State-Level Panel of Annual Inequality Measures over the Period 1916 - 2005" Journal of Business Strategies, vol. 31, no. 1, pages 241-263.

M. Frank, E. Sommeiller, M. Price and E. Saez (2015). “Frank-Sommeiller-Price Series for Top Income Shares by US States since 1917."

Johannesen, N. and G. Zucman (2014). “The End of Bank Secrecy? An Evaluation of the G20 Tax Haven Crackdown." American Economic Journal: Economic Policy, 6(1): 65-91.

Kleven, H., C. Landais and E. Saez (2013). “Taxation and International Migration of Superstars: Evidence from the European Football Market." American Economic Review, 2013.

Leigh, A. (2005)“Can Redistributive State Taxes Reduce Inequality?” Working paper

Liebig, T., P. Puhani and A. Sousa-Poza (2006). “Taxation and Internal Migration.” IZA working paper.

Moretti, E. and D. Wilson (2013). "State Incentives for Innovation, Star Scientists and Jobs." Working Paper.

Penniman, C. (1980). State Income Taxation. Baltimore: Johns Hopkins University Press.

Piketty, T. and E. Saez. (2003) “Income Inequality in the United States, 1913-1998." Quarterly Journal of Economics.

E. Saez, J. Slemrod, and S. H. Giertz " (2012) The Elasticity of Taxable Income with Respect to Marginal Tax Rates: A Critical Review," Journal of Economic Literature 50:1, 3-50

Saez, E. (2016)“Taxing the Rich More: Preliminary Evidence from the 2013 Tax Increase.” Working paper.

Saez, E. and G. Zucman (2016) "Wealth Inequality in the United States Since 1913: Evidence from Capitalized Income Tax Data." Quarterly Journal of Economics.

Troiano, U. (2017). “Intergovernmental Cooperation and Tax Enforcement.” NBER Working Paper. 
Table 1: Summary Statistics

\begin{tabular}{lrrrrr}
\hline & & & & \\
& Mean & Std. Dev. & Min. & Max. & Obs. \\
\hline Inequality Measures & & & & & \\
$\quad$ Atkinson Index & 0.20 & 0.06 & 0.05 & 0.51 & 4965 \\
Gini Coefficient & 0.49 & 0.08 & 0.23 & 0.75 & 4965 \\
Relative Mean Deviation & 0.68 & 0.12 & 0.31 & 1.22 & 4965 \\
Theil Index & 0.52 & 0.23 & 0.12 & 2.00 & 4965 \\
Income Share Top 10 percent & 37.43 & 6.44 & 18.02 & 69.54 & 4965 \\
Income Share Top 5 percent & 26.49 & 5.83 & 11.29 & 59.11 & 4965 \\
Income Share Top 1 percent & 13.10 & 4.58 & 3.76 & 46.18 & 4965 \\
Income Share Top 0.5 percent & 9.75 & 4.04 & 2.36 & 40.58 & 4965 \\
Income Share Top 0.1 percent & 4.98 & 2.92 & 0.76 & 27.59 & 4965 \\
Income Share Top 0.01 percent & 1.90 & 1.58 & 0.12 & 15.15 & 4965 \\
Policy Changes & & & & & \\
Post Income Tax Introduction & 0.69 & 0.46 & 0.00 & 1.00 & 4965 \\
Post Withholding Introduction & 0.44 & 0.50 & 0.00 & 1.00 & 4965 \\
Post Information Exchange Agreement & 0.48 & 0.50 & 0.00 & 1.00 & 4965 \\
\hline Notes Sample cover years 1917-2015. & & & & &
\end{tabular}

Notes: Sample covers years 1917-2015. . 
Table 2: Policy Changes

\begin{tabular}{|c|c|c|c|}
\hline & $\begin{array}{l}\text { Income Tax } \\
\text { Introduction }\end{array}$ & $\begin{array}{l}\text { Withholding } \\
\text { Introduction }\end{array}$ & $\begin{array}{l}\text { Information Exchange } \\
\text { Audit Agreement }\end{array}$ \\
\hline Alabama & 1933 & 1956 & 1970 \\
\hline Alaska & 1959 & 1959 & 1967 \\
\hline Arizona & 1933 & 1954 & 1966 \\
\hline Arkansas & 1929 & 1956 & 1963 \\
\hline California & 1935 & 1971 & 1961 \\
\hline Colorado & 1937 & 1954 & 1952 \\
\hline Connecticut & 1969 & & 1970 \\
\hline Delaware & 1917 & 1949 & 1965 \\
\hline Georgia & 1929 & 1960 & 1968 \\
\hline Hawaii & 1959 & 1959 & 1965 \\
\hline Idaho & 1931 & 1955 & 1964 \\
\hline Illinois & 1969 & 1969 & 1963 \\
\hline Indiana & 1963 & 1963 & 1961 \\
\hline Iowa & 1934 & 1966 & 1962 \\
\hline Kansas & 1933 & 1966 & 1960 \\
\hline Kentucky & 1936 & 1954 & 1951 \\
\hline Louisiana & 1934 & 1961 & 1971 \\
\hline Maine & 1969 & 1969 & 1964 \\
\hline Maryland & 1937 & 1955 & 1963 \\
\hline Massachusetts & 1916 & 1959 & 1963 \\
\hline Michigan & 1967 & 1967 & 1965 \\
\hline Minnesota & 1933 & 1961 & 1957 \\
\hline Mississippi & 1912 & 1968 & 1966 \\
\hline Missouri & 1917 & 1961 & 1962 \\
\hline Montana & 1933 & 1955 & 1951 \\
\hline Nebraska & 1967 & 1967 & 1963 \\
\hline New Jersey & 1976 & 1976 & 1966 \\
\hline New Mexico & 1933 & 1961 & 1963 \\
\hline New York & 1919 & 1959 & 1963 \\
\hline North Carolina & 1921 & 1959 & 1950 \\
\hline North Dakota & 1919 & & 1964 \\
\hline Ohio & 1971 & 1971 & 1961 \\
\hline Oklahoma & 1915 & 1961 & 1963 \\
\hline Oregon & 1930 & 1948 & 1961 \\
\hline Pennsylvania & 1971 & 1971 & 1965 \\
\hline Rhode Island & 1971 & 1971 & 1970 \\
\hline South Carolina & 1922 & 1959 & 1964 \\
\hline Tennessee & 1931 & & 1963 \\
\hline Utah & 1931 & 1959 & 1961 \\
\hline Vermont & 1931 & 1951 & 1965 \\
\hline Virginia & 1961 & 1963 & 1963 \\
\hline West Virginia & 1961 & 1961 & 1962 \\
\hline Wisconsin & 1911 & 1962 & 1950 \\
\hline
\end{tabular}


Table 3: Effects of Policy Changes on Inequality Measures

\begin{tabular}{|c|c|c|c|}
\hline & $\begin{array}{c}(1) \\
\text { Atkinson Index }\end{array}$ & $\begin{array}{c}\text { (2) } \\
\text { Atkinson Index }\end{array}$ & $\begin{array}{c}\text { (3) } \\
\text { Atkinson Index }\end{array}$ \\
\hline Post Income Tax Introduction & $\begin{array}{c}0.0149^{* * *} \\
(0.0051)\end{array}$ & & \\
\hline Post Withholding Introduction & & $\begin{array}{l}0.0114^{* *} \\
(0.0044)\end{array}$ & \\
\hline Post Information Exchange Agreement & & & $\begin{array}{c}0.00821^{*} \\
(0.0041)\end{array}$ \\
\hline State Fixed Effects & Yes & Yes & Yes \\
\hline Year Fixed Effects & Yes & Yes & Yes \\
\hline State Effects Interacted with Linear Trend & Yes & Yes & Yes \\
\hline Observations & 4965 & 4965 & 4965 \\
\hline$R^{2}$ & 0.881 & 0.880 & 0.879 \\
\hline
\end{tabular}

Notes: Estimates are obtained by OLS. Heteroskedasticity-robust standard errors are clustered at the state level. Sample covers years 1917-2015. 
Table 4: Effects of Policy Changes on Inequality Measures

\begin{tabular}{lccc}
\hline \hline & $\begin{array}{c}(1) \\
\text { Gini Coefficient }\end{array}$ & $\begin{array}{c}(2) \\
\text { Gini Coefficient }\end{array}$ & $\begin{array}{c}(3) \\
\text { Gini Coefficient }\end{array}$ \\
\hline Post Income Tax Introduction & $\begin{array}{c}0.0143^{* *} \\
(0.0061)\end{array}$ & & \\
Post Withholding Introduction & & & \\
& & $0.00891^{*}$ & \\
& & $(0.0052)$ & \\
Post Information Exchange Agreement & & & 0.00534 \\
& & & $(0.0048)$ \\
State Fixed Effects & Yes & Yes & Yes \\
Year Fixed Effects & Yes & Yes & Yes \\
State Effects Interacted with Linear Trend & Yes & Yes & Yes \\
\hline $\begin{array}{l}\text { Observations } \\
R^{2}\end{array}$ & 4965 & 4965 & 4965 \\
\hline \hline Standard errors in parentheses & 0.907 & 0.906 & 0.906 \\
\hline
\end{tabular}

Notes: Estimates are obtained by OLS. Heteroskedasticity-robust standard errors are clustered at the state level. Sample covers years 1917-2015. 
Table 5: Effects of Policy Changes on Inequality Measures

\begin{tabular}{|c|c|c|c|}
\hline & $\begin{array}{c}\text { (1) } \\
\text { Relative Mean Deviation }\end{array}$ & $\begin{array}{c}(2) \\
\text { Relative Mean Deviation }\end{array}$ & $\begin{array}{c}\text { (3) } \\
\text { Relative Mean Deviation }\end{array}$ \\
\hline Post Income Tax Introduction & $\begin{array}{l}0.0276^{* *} \\
(0.0110)\end{array}$ & & \\
\hline Post Withholding Introduction & & $\begin{array}{c}0.0155 \\
(0.0104)\end{array}$ & \\
\hline Post Information Exchange Agreement & & & $\begin{array}{c}0.0134 \\
(0.0081)\end{array}$ \\
\hline State Fixed Effects & Yes & Yes & Yes \\
\hline Year Fixed Effects & Yes & Yes & Yes \\
\hline State Effects Interacted with Linear Trend & Yes & Yes & Yes \\
\hline Observations & 4965 & 4965 & 4965 \\
\hline$R^{2}$ & 0.883 & 0.881 & 0.881 \\
\hline
\end{tabular}

Notes: Estimates are obtained by OLS. Heteroskedasticity-robust standard errors are clustered at the state level. Sample covers years 1917-2015. 
Table 6: Effects of Policy Changes on Inequality Measures

\begin{tabular}{|c|c|c|c|}
\hline & $\begin{array}{c}\text { (1) } \\
\text { Theil Index }\end{array}$ & $\begin{array}{c}(2) \\
\text { Theil Index }\end{array}$ & $\begin{array}{c}(3) \\
\text { Theil Index }\end{array}$ \\
\hline Post Income Tax Introduction & $\begin{array}{c}0.0596^{* * *} \\
(0.0191)\end{array}$ & & \\
\hline Post Withholding Introduction & & $\begin{array}{c}0.0536^{* * *} \\
(0.0165)\end{array}$ & \\
\hline Post Information Exchange Agreement & & & $\begin{array}{c}0.0358^{* *} \\
(0.0168)\end{array}$ \\
\hline State Fixed Effects & Yes & Yes & Yes \\
\hline Year Fixed Effects & Yes & Yes & Yes \\
\hline State Effects Interacted with Linear Trend & Yes & Yes & Yes \\
\hline Observations & 4965 & 4965 & 4965 \\
\hline$R^{2}$ & 0.867 & 0.866 & 0.865 \\
\hline
\end{tabular}

Notes: Estimates are obtained by OLS. Heteroskedasticity-robust standard errors are clustered at the state level. Sample covers years 1917-2015. 
Table 7: Effects of Policy Changes on Inequality Measures

\begin{tabular}{lcc}
\hline \hline & $(1)$ & $(2)$ \\
& Atkinson Index & Gini \\
\hline Post Withholding & $0.00926^{* *}$ & $0.0103^{* *}$ \\
& $(0.0043)$ & $(0.0048)$ \\
State Fixed Effects & Yes & Yes \\
Year Fixed Effects & Yes & Yes \\
State Effects Interacted with Linear Trend & Yes & Yes \\
Exemptions and Deductions * Conformity & Yes & Yes \\
\hline Observations & 3800 & 3800 \\
$R^{2}$ & 0.857 & 0.901 \\
\hline \hline
\end{tabular}

Standard errors in parentheses

${ }^{*} p<0.10,{ }^{* *} p<0.05,{ }^{* * *} p<0.01$

Table 8: Effects of Policy Changes on Inequality Measures

\begin{tabular}{lcc}
\hline \hline & $(1)$ & $(2)$ \\
& Relative Mean Deviation & Theil Index \\
\hline Post Withholding & 0.0159 & $0.0397^{* *}$ \\
& $(0.0104)$ & $(0.0166)$ \\
State Fixed Effects & Yes & Yes \\
Year Fixed Effects & Yes & Yes \\
State Effects Interacted with Linear Trend & Yes & Yes \\
Exemptions and Deductions * Conformity & Yes & Yes \\
\hline Observations & 3800 & 3800 \\
$R^{2}$ & 0.867 & 0.837 \\
\hline \hline
\end{tabular}

Standard errors in parentheses

${ }^{*} p<0.10,{ }^{* *} p<0.05,{ }^{* * *} p<0.01$ 
Table 9: Effects of Policy Changes on Inequality Measures

\begin{tabular}{lcc}
\hline \hline & $\begin{array}{c}(1) \\
\text { Atksinson Index }\end{array}$ & $\begin{array}{c}(2) \\
\text { Gini Coefficient }\end{array}$ \\
\hline Post Information Agreement & $0.00829^{* *}$ & 0.00555 \\
& $(0.0040)$ & $(0.0045)$ \\
State Fixed Effects & Yes & Yes \\
Year Fixed Effects & Yes & Yes \\
State Effects Interacted with Linear Trend & Yes & Yes \\
State Effects Interacted with Federal Surplus & Yes & Yes \\
\hline Observations & 4965 & 4965 \\
$R^{2}$ & 0.887 & 0.912 \\
\hline \hline
\end{tabular}

Standard errors in parentheses

${ }^{*} p<0.10,{ }^{* *} p<0.05,{ }^{* * *} p<0.01$

Table 10: Effects of Policy Changes on Inequality Measures

\begin{tabular}{lcc}
\hline \hline & $(1)$ & $(2)$ \\
& Relative Mean Deviation & Theil Index \\
\hline Post Information Agreement & $0.0136^{*}$ & $0.0351^{* *}$ \\
& $(0.0076)$ & $(0.0164)$ \\
State Fixed Effects & Yes & Yes \\
Year Fixed Effects & Yes & Yes \\
State Effects Interacted with Linear Trend & Yes & Yes \\
State Effects Interacted with Federal Surplus & Yes & Yes \\
\hline Observations & 4965 & 4965 \\
$R^{2}$ & 0.889 & 0.873 \\
\hline \hline
\end{tabular}

Standard errors in parentheses

${ }^{*} p<0.10,{ }^{* *} p<0.05,{ }^{* * *} p<0.01$ 
Table 11: Effects of Policy Changes on Inequality - Other Measures

\begin{tabular}{|c|c|c|c|}
\hline & $\begin{array}{c}\text { (1) } \\
\text { Income Share Top } 0.01 \text { percent }\end{array}$ & $\begin{array}{c}\text { (2) } \\
\text { Income Share Top } 0.01 \text { percent }\end{array}$ & $\begin{array}{c}\text { (3) } \\
\text { Income Share Top } 0.01 \text { percent }\end{array}$ \\
\hline Post Individual Income Tax & $\begin{array}{l}0.277^{* * *} \\
(0.0954)\end{array}$ & & \\
\hline Post Withholding & & $\begin{array}{l}0.415^{* * *} \\
(0.1546)\end{array}$ & \\
\hline Post Information Agreement & & & $\begin{array}{c}0.182 \\
(0.1532)\end{array}$ \\
\hline State Fixed Effects & Yes & Yes & Yes \\
\hline Year Fixed Effects & Yes & Yes & Yes \\
\hline State Effects Interacted with Linear Trend & Yes & Yes & Yes \\
\hline Observations & 4965 & 4965 & 4965 \\
\hline$R^{2}$ & 0.817 & 0.818 & 0.816 \\
\hline
\end{tabular}

${ }^{*} p<0.10,{ }^{* *} p<0.05,{ }^{* * *} p<0.01$

Notes: Estimates are obtained by OLS. Heteroskedasticity-robust standard errors are clustered at the state level. Sample covers years 1917-2015. 
Table 12: Effects of Policy Changes on Inequality - Other Measures

\begin{tabular}{lccc}
\hline \hline & $(1)$ & $(2)$ & $(3)$ \\
& Income Share Top 0.1 percent & Income Share Top 0.1 percent & Income Share Top 0.1 percent \\
\hline Post Individual Income Tax & $0.536^{* * *}$ & & \\
& $(0.1975)$ & $0.660^{* * *}$ \\
Post Withholding & & $(0.2387)$ & \\
& & & 0.342 \\
Post Information Agreement & & & $(0.2370)$ \\
& & Yes & Yes \\
State Fixed Effects & Yes & Yes & Yes \\
Year Fixed Effects & Yes & Yes & Yes \\
State Effects Interacted with Linear Trend & Yes & 4965 & 4965 \\
\hline Observations & 4965 & 0.852 & 0.851 \\
$R^{2}$ & 0.852 & & \\
\hline \hline Standard errors in parentheses & & &
\end{tabular}

${ }^{*} p<0.10,{ }^{* *} p<0.05,{ }^{* * *} p<0.01$

Notes: Estimates are obtained by OLS. Heteroskedasticity-robust standard errors are clustered at the state level. Sample covers years 1917-2015. 
Table 13: Effects of Policy Changes on Inequality - Other Measures

\begin{tabular}{|c|c|c|c|}
\hline & $\begin{array}{c}\text { (1) } \\
\text { Income Share Top 0.5 percent }\end{array}$ & $\begin{array}{c}\text { (2) } \\
\text { Income Share Top 0.5 percent }\end{array}$ & $\begin{array}{c}\text { (3) } \\
\text { Income Share Top } 0.5 \text { percent }\end{array}$ \\
\hline Post Individual Income Tax & $\begin{array}{l}0.844^{* *} \\
(0.3249)\end{array}$ & & \\
\hline Post Withholding & & $\begin{array}{l}0.746^{* *} \\
(0.2988)\end{array}$ & \\
\hline Post Information Agreement & & & $\begin{array}{c}0.497^{*} \\
(0.2912)\end{array}$ \\
\hline State Fixed Effects & Yes & Yes & Yes \\
\hline Year Fixed Effects & Yes & Yes & Yes \\
\hline State Effects Interacted with Linear Trend & Yes & Yes & Yes \\
\hline Observations & 4965 & 4965 & 4965 \\
\hline$R^{2}$ & 0.863 & 0.862 & 0.861 \\
\hline
\end{tabular}

${ }^{*} p<0.10,{ }^{* *} p<0.05,{ }^{* * *} p<0.01$

Notes: Estimates are obtained by OLS. Heteroskedasticity-robust standard errors are clustered at the state level. Sample covers years 1917-2015. 
Table 14: Effects of Policy Changes on Inequality - Other Measures

\begin{tabular}{lccc}
\hline \hline & $(1)$ & $(2)$ & $(3)$ \\
& Income Share Top 1 percent & Income Share Top 1 percent & Income Share Top 1 percent \\
\hline Post Individual Income Tax & $0.984^{* *}$ & & \\
& $(0.3927)$ & $0.794^{* *}$ \\
Post Withholding & & $(0.3518)$ & $0.646^{* *}$ \\
& & & $(0.3142)$ \\
Post Information Agreement & & & Yes \\
& & Yes & Yes \\
State Fixed Effects & Yes & Yes & Yes \\
Year Fixed Effects & Yes & Yes & 4965 \\
State Effects Interacted with Linear Trend & Yes & 4965 & 0.866 \\
\hline Observations & 4965 & & 0.866 \\
$R^{2}$ & 0.867 & & \\
\hline \hline Standard errors in parentheses & & &
\end{tabular}

${ }^{*} p<0.10,{ }^{* *} p<0.05,{ }^{* * *} p<0.01$

Notes: Estimates are obtained by OLS. Heteroskedasticity-robust standard errors are clustered at the state level. Sample covers years 1917-2015. 
Table 15: Effects of Policy Changes on Inequality - Other Measures

\begin{tabular}{lccc}
\hline \hline & $(1)$ & $(2)$ & $(3)$ \\
& Income Share Top 5 percent & Income Share Top 5 percent & Income Share Top 5 percent \\
\hline Post Individual Income Tax & $1.182^{*}$ & & \\
& $(0.6221)$ & 0.617 \\
Post Withholding & & $(0.4904)$ & \\
& & & 0.500 \\
Post Information Agreement & & & $(0.4337)$ \\
& & Yes & Yes \\
State Fixed Effects & Yes & Yes & Yes \\
Year Fixed Effects & Yes & Yes & Yes \\
State Effects Interacted with Linear Trend & Yes & 4965 & 4965 \\
\hline Observations & 4965 & 0.845 & 0.844 \\
$R^{2}$ & 0.846 & & \\
\hline \hline Standard errors in parentheses & & & \\
\hline
\end{tabular}

${ }^{*} p<0.10,{ }^{* *} p<0.05,{ }^{* * *} p<0.01$

Notes: Estimates are obtained by OLS. Heteroskedasticity-robust standard errors are clustered at the state level. Sample covers years 1917-2015. 
Table 16: Effects of Policy Changes on Inequality - Other Measures

\begin{tabular}{|c|c|c|c|}
\hline & $\begin{array}{c}\text { (1) } \\
\text { Income Share Top } 10 \text { percent }\end{array}$ & $\begin{array}{c}\text { (2) } \\
\text { Income Share Top } 10 \text { percent }\end{array}$ & $\begin{array}{c}\text { (3) } \\
\text { Income Share Top } 10 \text { percent }\end{array}$ \\
\hline Post Individual Income Tax & $\begin{array}{c}1.663^{*} \\
(0.9218)\end{array}$ & & \\
\hline Post Withholding & & $\begin{array}{c}0.424 \\
(0.7171)\end{array}$ & \\
\hline Post Information Agreement & & & $\begin{array}{c}0.467 \\
(0.6960)\end{array}$ \\
\hline State Fixed Effects & Yes & Yes & Yes \\
\hline Year Fixed Effects & Yes & Yes & Yes \\
\hline State Effects Interacted with Linear Trend & Yes & Yes & Yes \\
\hline Observations & 4965 & 4965 & 4965 \\
\hline$R^{2}$ & 0.801 & 0.798 & 0.798 \\
\hline
\end{tabular}

${ }^{*} p<0.10,{ }^{* *} p<0.05,{ }^{* * *} p<0.01$

Notes: Estimates are obtained by OLS. Heteroskedasticity-robust standard errors are clustered at the state level. Sample covers years 1917-2015. 
Figure 1: The Importance of State Personal Income Tax Revenues for State Total Revenues

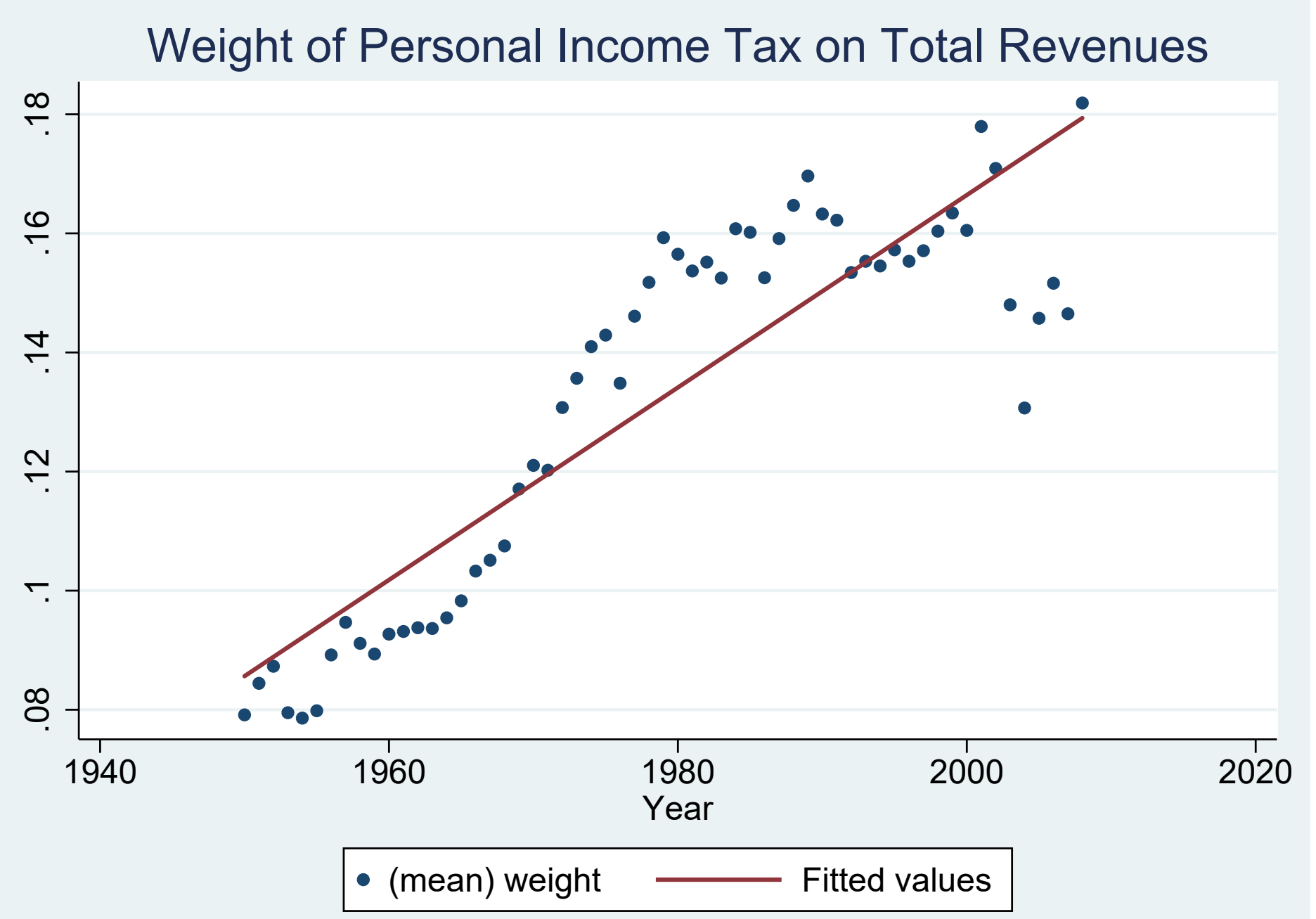

Notes: Sample covers years 1917-2015. 
Figure 2: The Importance of Total State Tax Revenues for Total State Revenues

\section{Weight of Tax Revenues on Total Revenues}

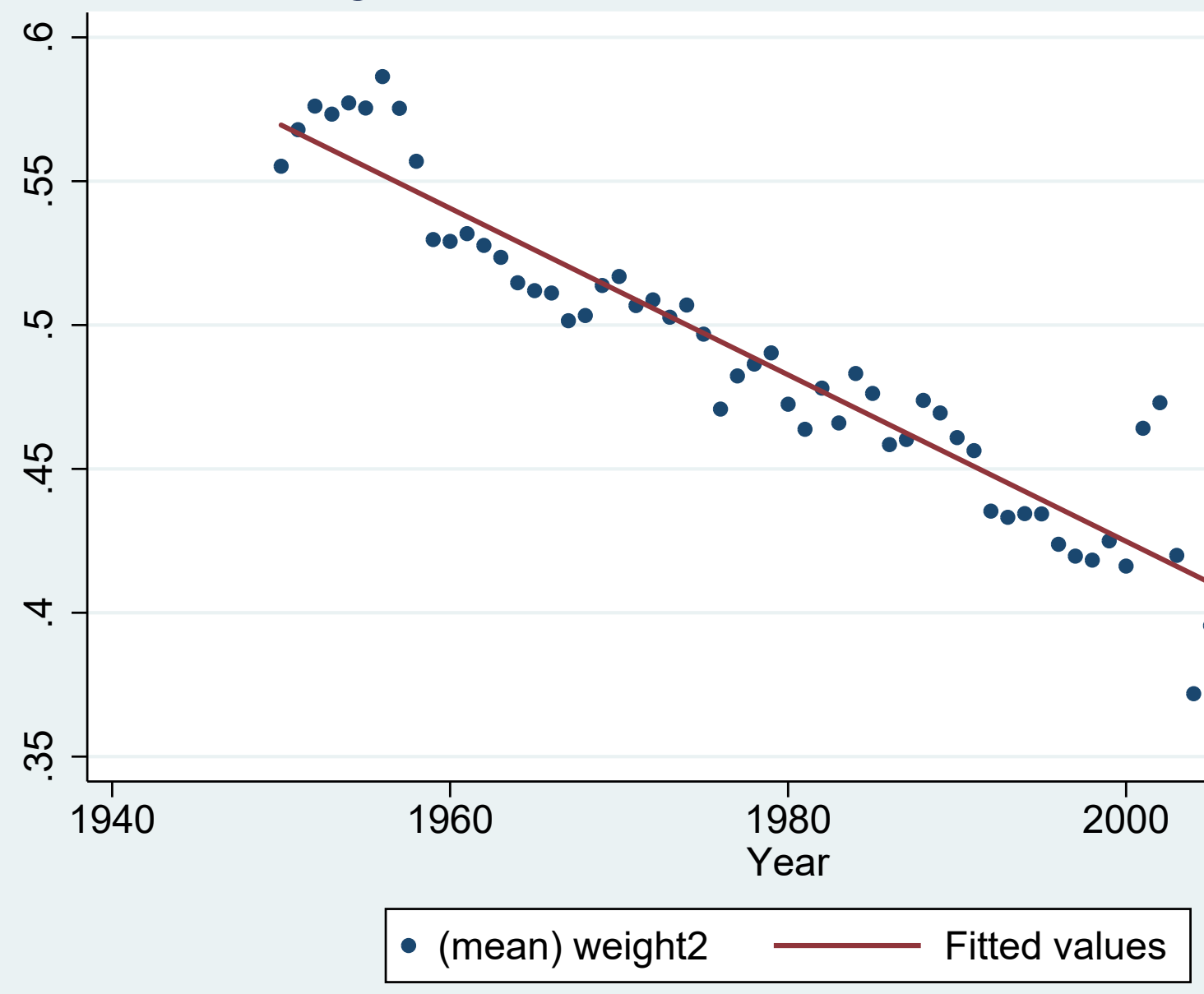

Notes: Sample covers years 1917-2015. 
Figure 3: Inequality Pre-trends
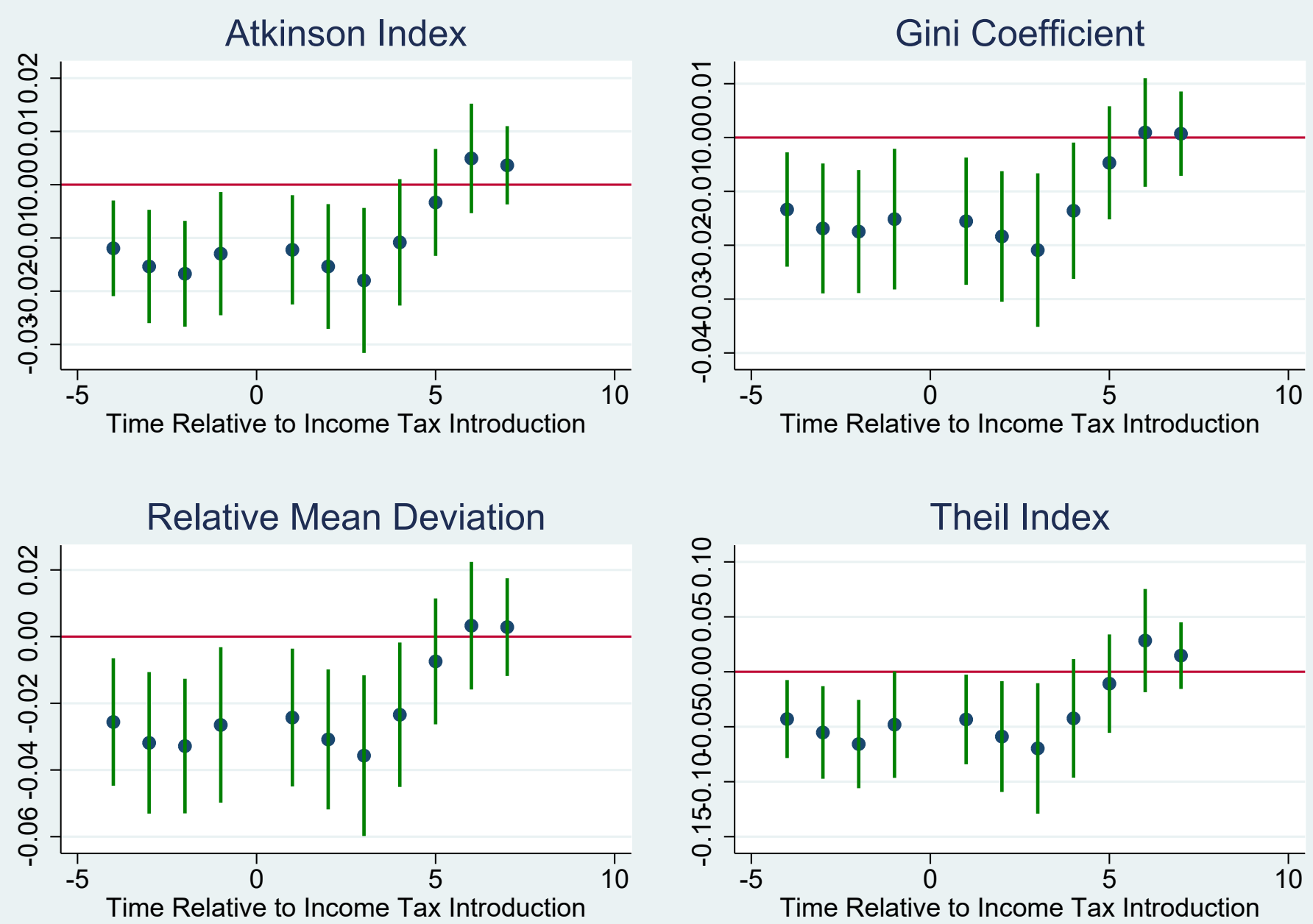

Notes: Sample covers years 1917-2015. 
Figure 4: Inequality Pre-trends
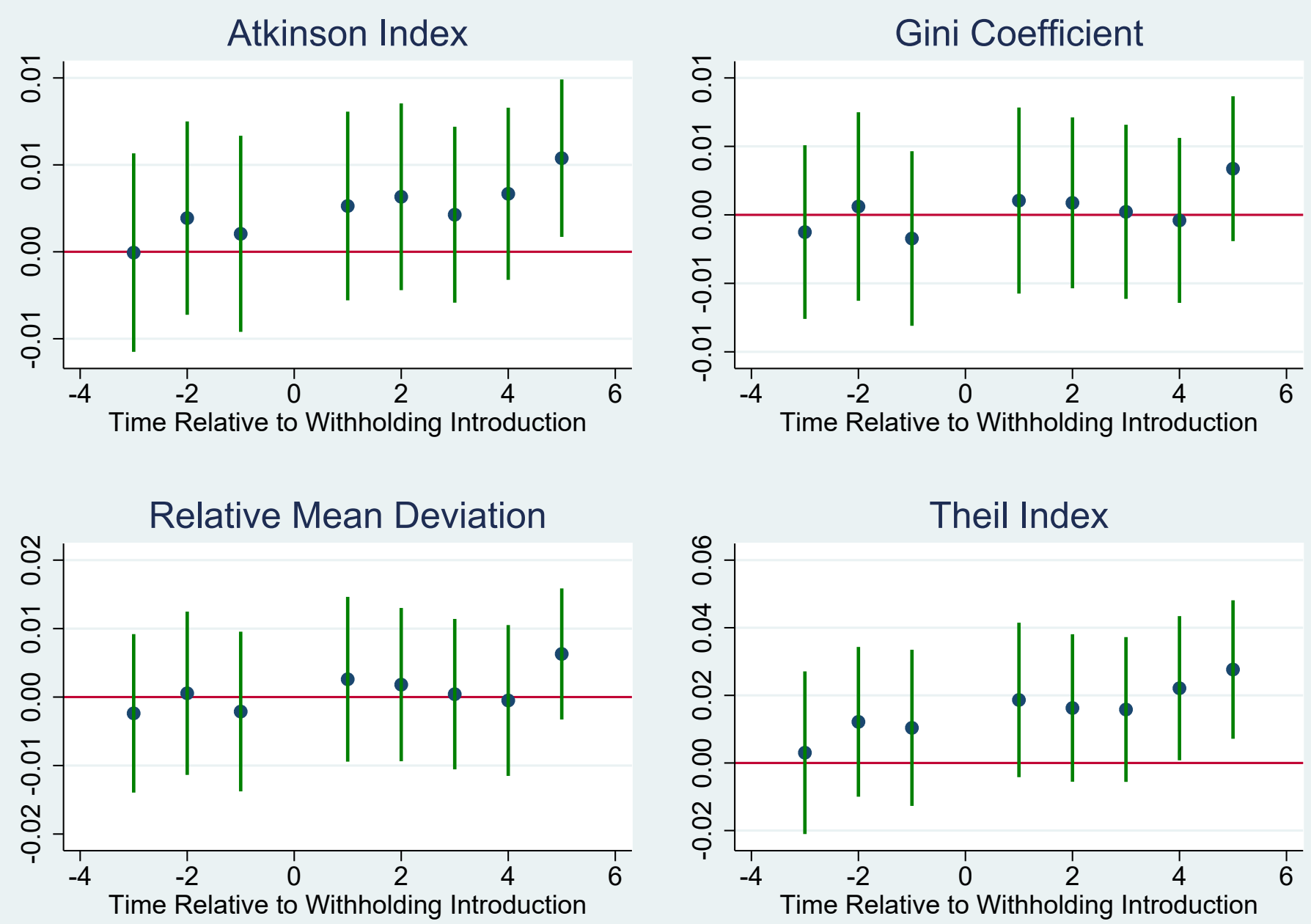

Notes: Sample covers years 1917-2015. 
Figure 5: Inequality Pre-trends
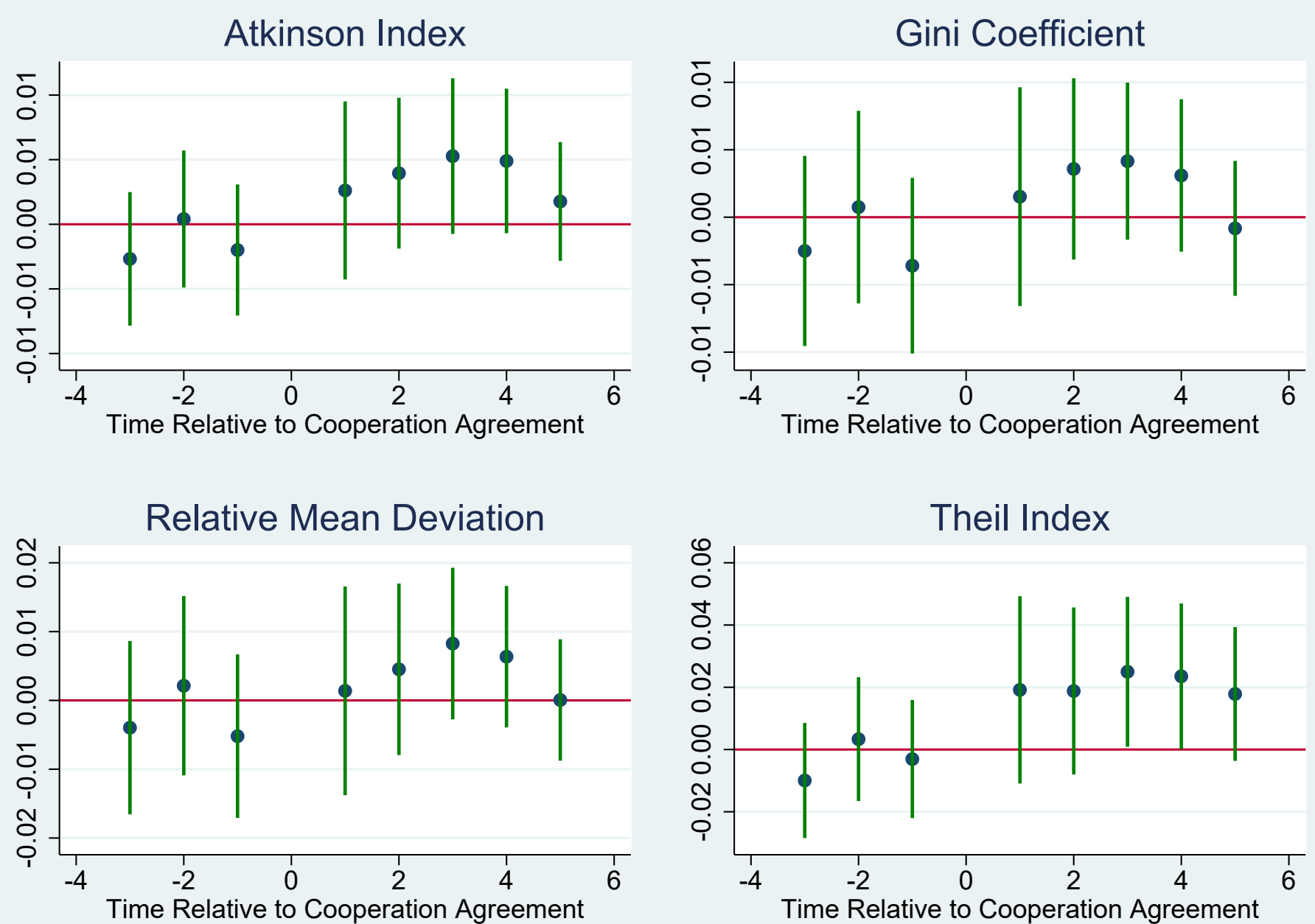

Notes: Sample covers years 1917-2015. 
Figure 6: Inequality Pre-trends
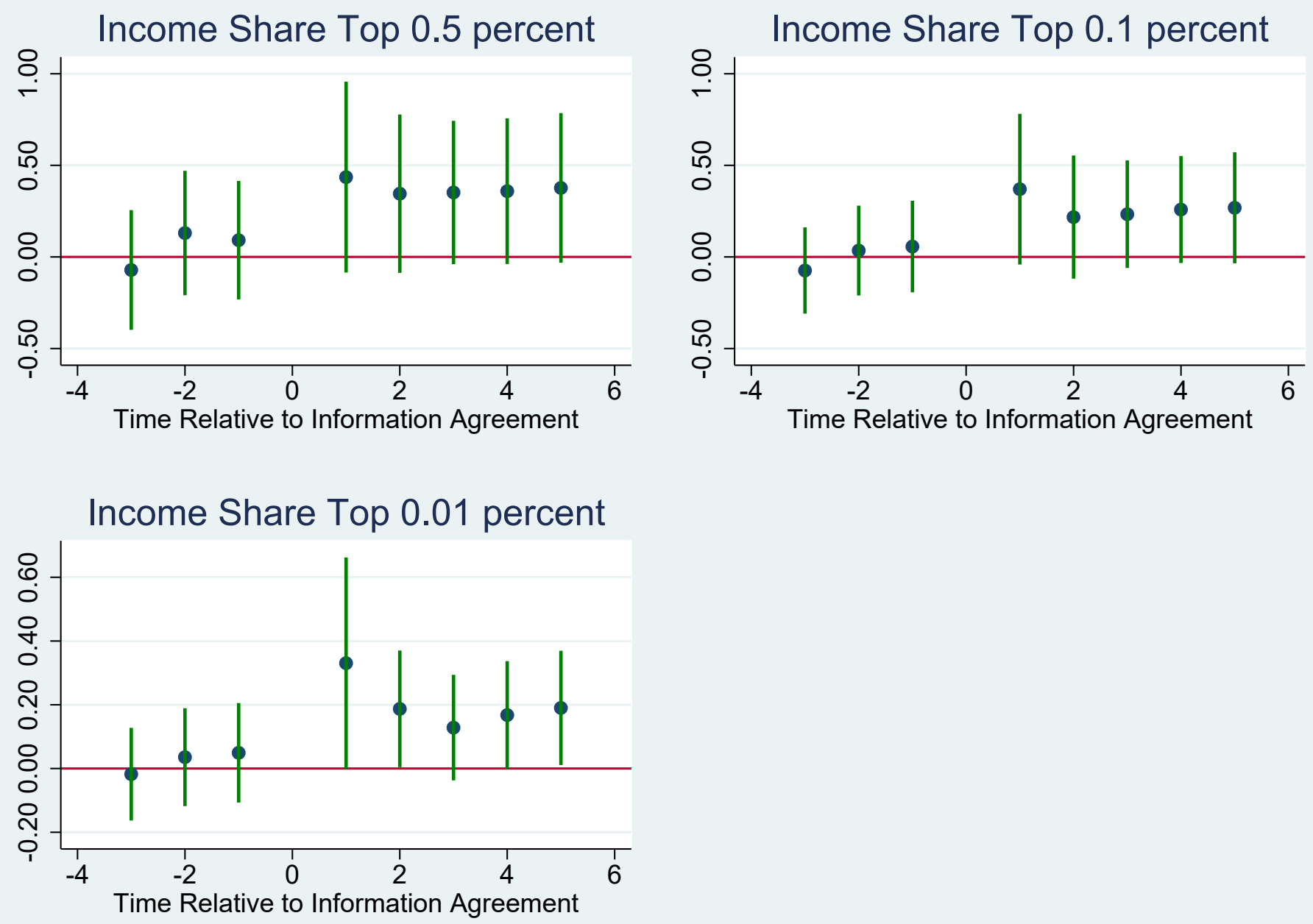

Notes: Sample covers years 1917-2015. 
Figure 7: Inequality Pre-trends
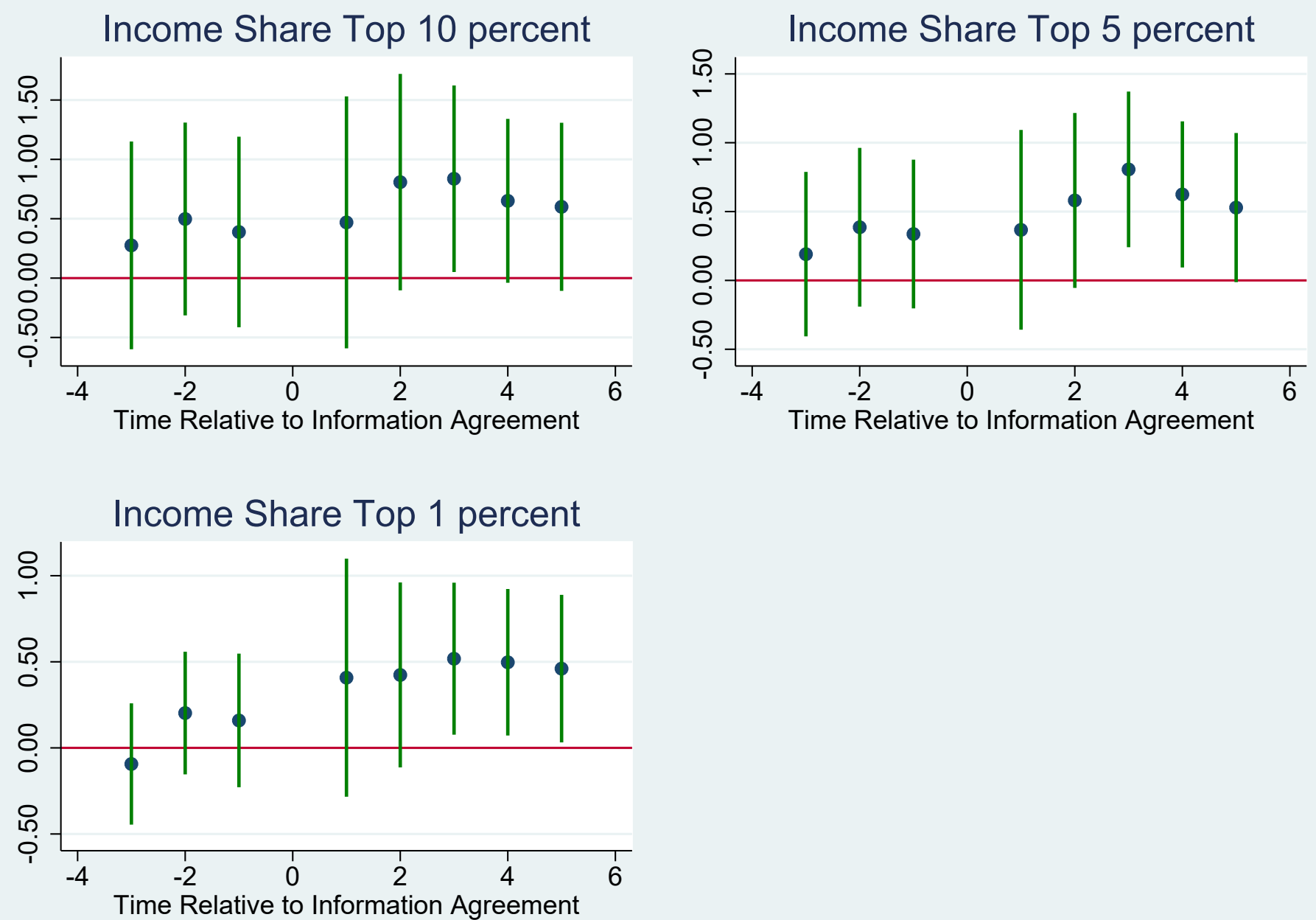

Notes: Sample covers years 1917-2015. 
Figure 8: Inequality Pre-trends
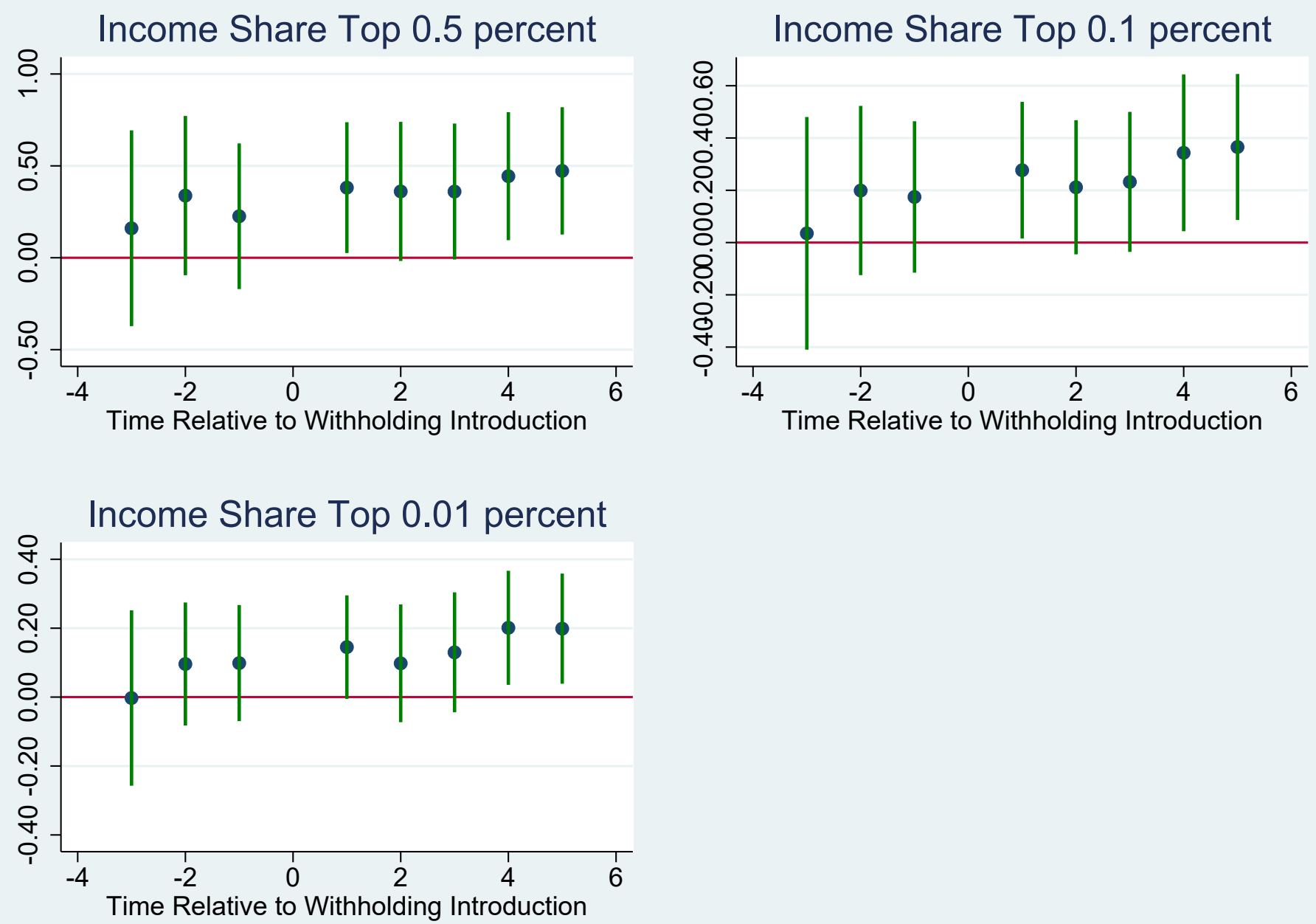

Notes: Sample covers years 1917-2015. 
Figure 9: Inequality Pre-trends
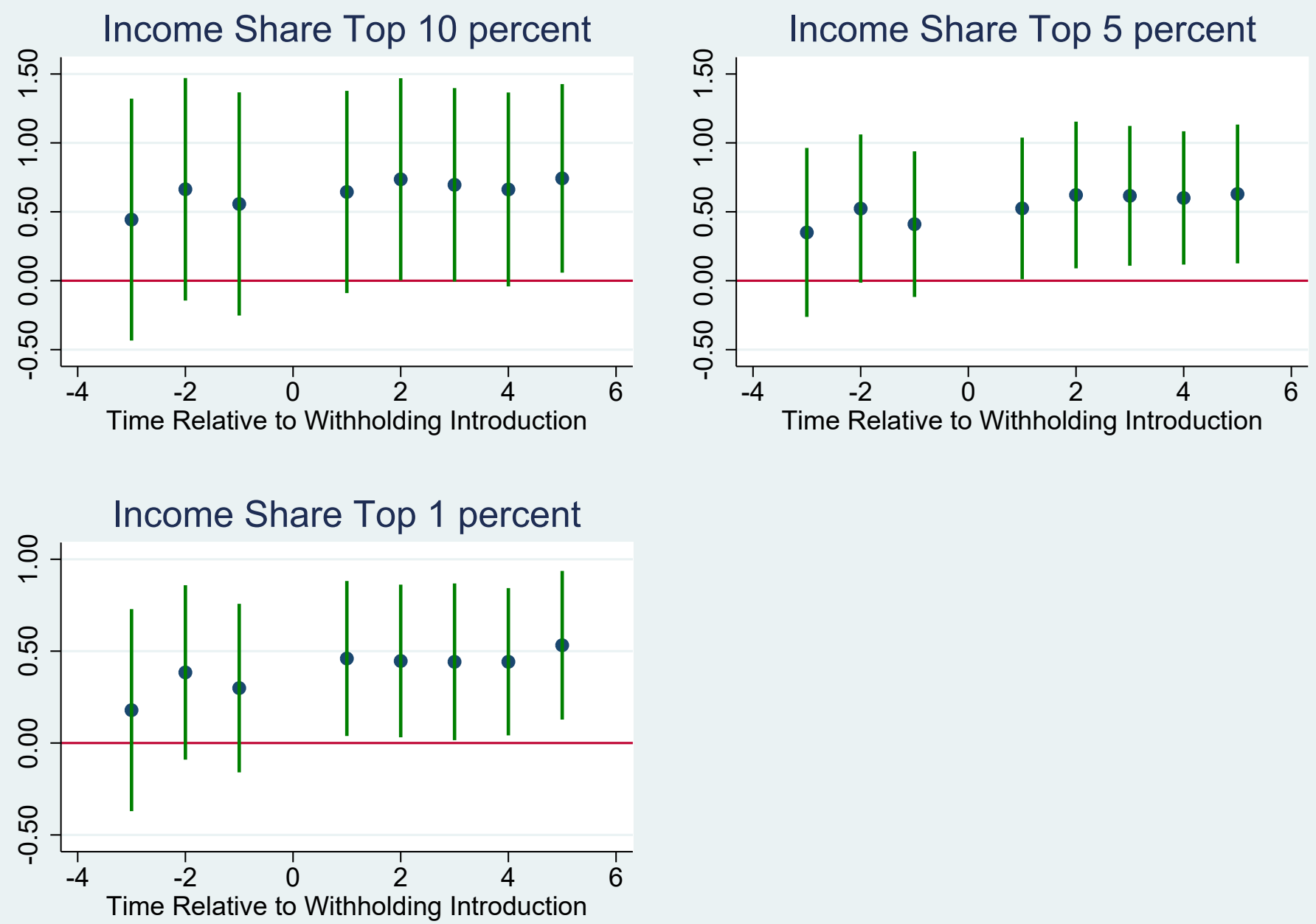

Notes: Sample covers years 1917-2015. 
Figure 10: Inequality Pre-trends
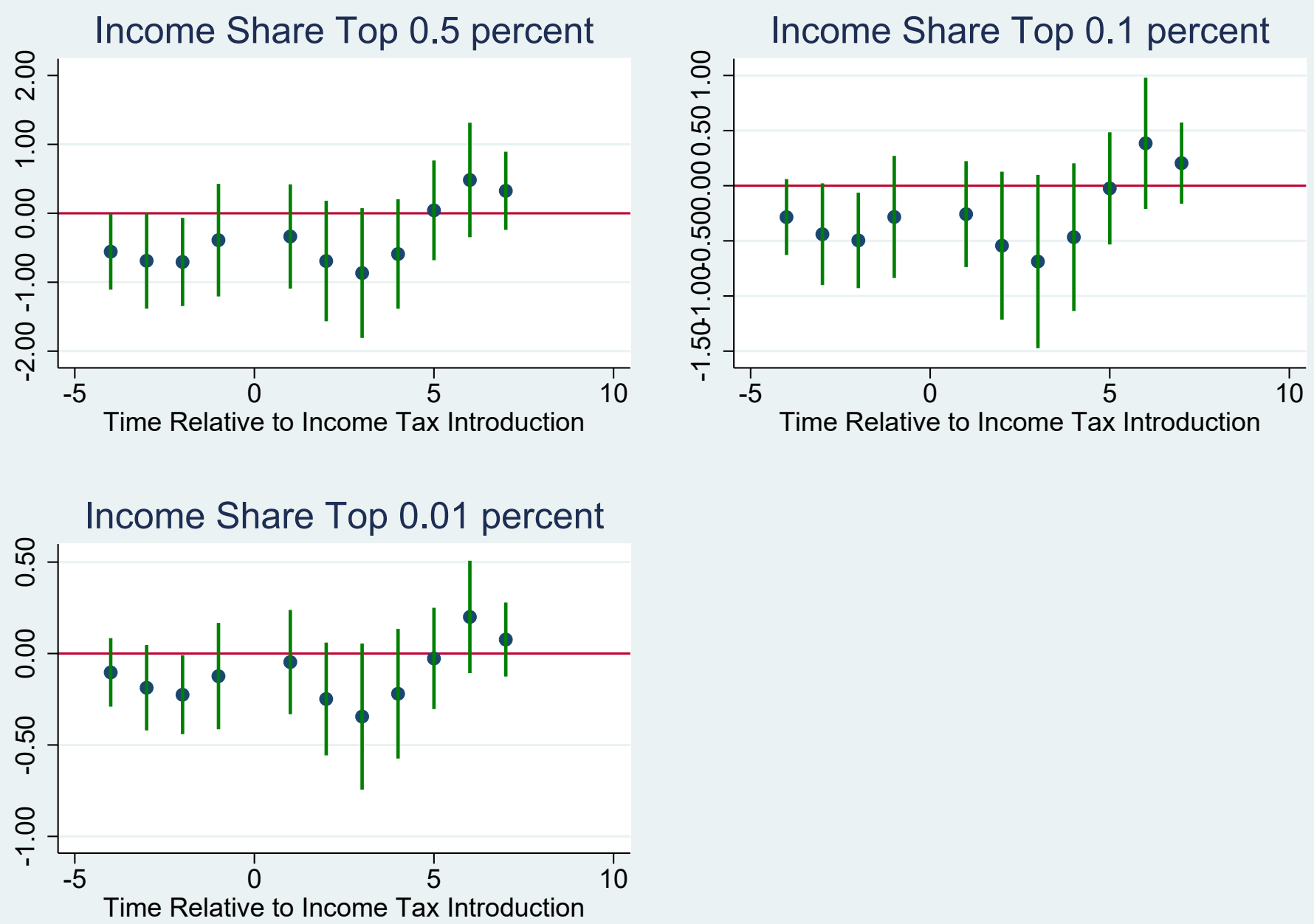

Notes: Sample covers years 1917-2015. 
Figure 11: Inequality Pre-trends
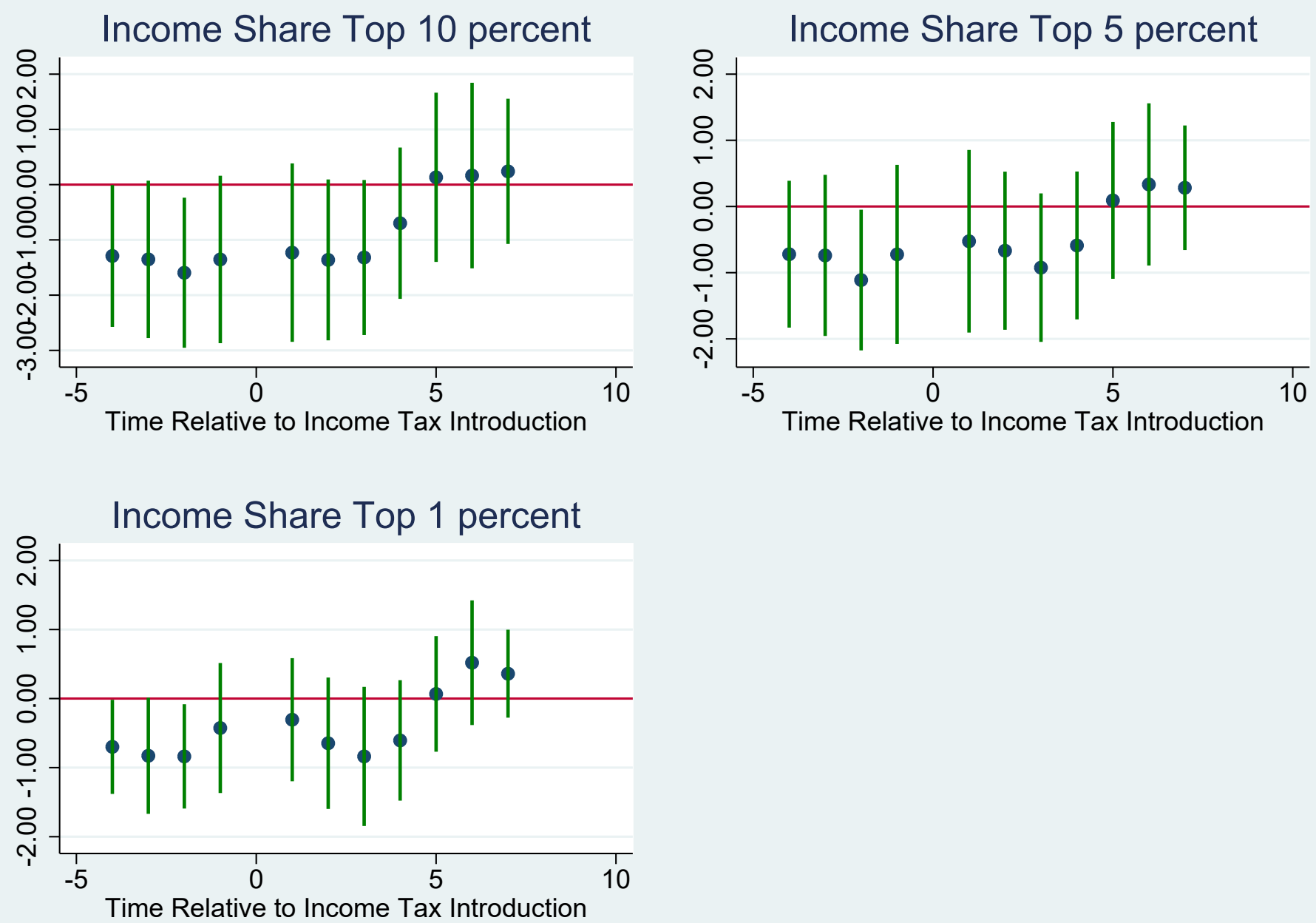

Notes: Sample covers years 1917-2015. 